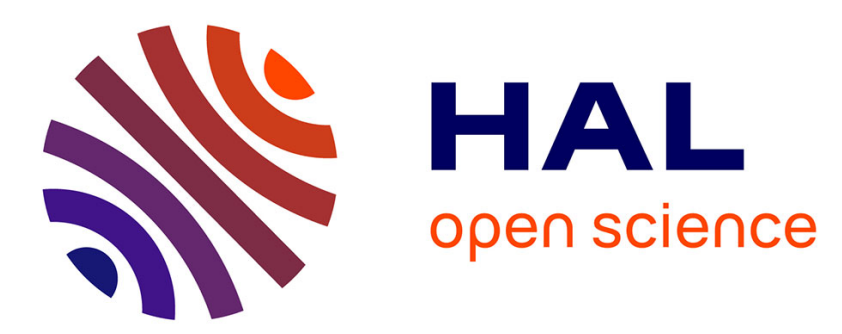

\title{
Clam dredging effects and subsequent recovery of benthic communities at different depth ranges
}

R. Constantino, M.B. Gaspar, J. Tata-Regala, S. Carvalho, J. Cúrdia, T. Drago, R. Taborda, C.C. Monteiro

\section{- To cite this version:}

R. Constantino, M.B. Gaspar, J. Tata-Regala, S. Carvalho, J. Cúrdia, et al.. Clam dredging effects and subsequent recovery of benthic communities at different depth ranges. Marine Environmental Research, 2009, 67 (2), pp.89. 10.1016/j.marenvres.2008.12.001 . hal-00501987

\section{HAL Id: hal-00501987 \\ https://hal.science/hal-00501987}

Submitted on 13 Jul 2010

HAL is a multi-disciplinary open access archive for the deposit and dissemination of scientific research documents, whether they are published or not. The documents may come from teaching and research institutions in France or abroad, or from public or private research centers.
L'archive ouverte pluridisciplinaire HAL, est destinée au dépôt et à la diffusion de documents scientifiques de niveau recherche, publiés ou non, émanant des établissements d'enseignement et de recherche français ou étrangers, des laboratoires publics ou privés. 


\section{Accepted Manuscript}

Clam dredging effects and subsequent recovery of benthic communities at different depth ranges

R. Constantino, M.B. Gaspar, J. Tata-Regala, S. Carvalho, J. Cúrdia, T. Drago,

R. Taborda, C.C. Monteiro

PII:

S0141-1136(08)00248-1

DOI:

10.1016/j.marenvres.2008.12.001

Reference:

MERE 3305

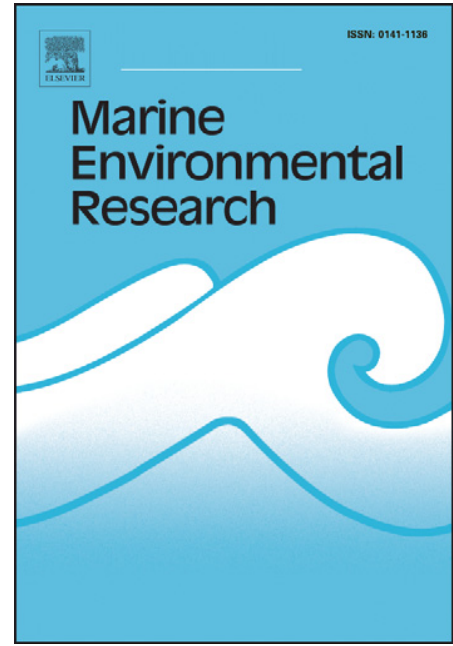

To appear in:

Marine Environmental Research

Received Date:

6 May 2008

Revised Date:

26 November 2008

Accepted Date:

2 December 2008

Please cite this article as: Constantino, R., Gaspar, M.B., Tata-Regala, J., Carvalho, S., Cúrdia, J., Drago, T., Taborda, R., Monteiro, C.C., Clam dredging effects and subsequent recovery of benthic communities at different depth ranges, Marine Environmental Research (2008), doi: 10.1016/j.marenvres.2008.12.001

This is a PDF file of an unedited manuscript that has been accepted for publication. As a service to our customers we are providing this early version of the manuscript. The manuscript will undergo copyediting, typesetting, and review of the resulting proof before it is published in its final form. Please note that during the production process errors may be discovered which could affect the content, and all legal disclaimers that apply to the journal pertain. 


\section{Title}

Clam dredging effects and subsequent recovery of benthic communities at different depth ranges

\section{Authors}

R. Constantino ${ }^{1}$, M.B. Gaspar ${ }^{1 *}$, J. Tata-Regala $^{1}$, S. Carvalho $^{1}$, J. Cúrdia $^{1}$, T. Drago ${ }^{1}$, R. Taborda $^{2}$, C.C. Monteiro ${ }^{1}$

\section{Affiliations of the authors:}

${ }^{1}$ Instituto Nacional dos Recursos Biológicos (INRB, I.P.)/ IPIMAR, Av. 5 de Outubro s/n, 8700-305 Olhão, Portugal.

${ }^{2}$ LATTEX, IDL, Faculdade de Ciências da Universidade de Lisboa, Campo Grande, 1749-016 Lisboa, Portugal.

\section{*Corresponding Author:}

Tel: $\quad+351289700500$

Fax: $\quad+351289700535$

E-mail: mbgaspar@cripsul.ipimar.pt

\section{KEYWORDS}

Ecosystem disturbance; Environmental impact; Fisheries; Bivalve dredging; Natural variability; Macrobenthic communities; Meiobenthic communities; Southern Portugal 


\section{ABSTRACT}

The present study aimed to assess the potential effects of clam dredging and the subsequent recovery of the benthic environment. Two experimental areas located at 6 and $18 \mathrm{~m}$ depth were established in order to analyse whether impacts and recovery of benthic environment are depth-related. Study areas were located within an area closed to dredging and two different plots were established at both depths. One of the plots was subjected to intense clam dredge-fishing, while the other was undisturbed and therefore used as control. Sampling followed a BACI design, with samples for macrobenthic, meiobenthic and sediment particle size analysis being taken by SCUBA divers from both areas before and after fishing stress. For both depths, impacts on the benthic environment were very low resulting in high recovery rates. Nevertheless, at shallower depths communities demonstrated a faster recovery. It was shown that depending on the faunal component used as a bioindicator, different results can be observed. Generally deposit-feeding organisms with scales or chitinous plates and vermiform shape (mainly crustaceans, polychaetes and ophiuroids), without external protection, were the most affected by dredging, while some polychaetes without external protection and with a carnivorous feeding mode seemed to be enhanced by fishing. The low level of perturbations induced by the dredging activities was comparable to the impact of surface waves on the bottom, as experiments were undertaken in wave-dominated environments. The coexistence of storm events during the study period proved to have similar or even more deleterious effects on the benthic environment. It appears that communities from hydrodynamic fishing grounds that are well adapted to natural physical stress are not highly affected by dredging. 


\section{INTRODUCTION}

The deleterious impact of bottom dredge and trawl fisheries on the benthic environment has been extensively documented worldwide (e.g. Dolmer and Frandsen, 2002; Carbines et al., 2004). According to the studies undertaken in subtidal grounds the magnitude of the impacts caused by such fisheries depends on several factors, namely gear type, habitat, depth, benthic communities and scale of disturbance (Collie et al., 2000). Therefore, the magnitude of the impacts can range from no detrimental post-fishing effects (e.g. Cranfield et al., 1999; Hall-Spencer and Moore, 2000; Hiddink, 2003; Carbines et al., 2004) to major disturbance effects in benthic communities (e.g. Kaiser et al., 1998; Hall-Spencer et al., 1999; Gutiérrez et al., 2004; Pranovi et al., 2004), with moderate disturbance effects being referenced by other authors (e.g. Hall et al., 1990; Schratzberger et al., 2002; Gaspar et al., 2003).

One of the main issues in fisheries management is the recovery time of the exploited environments. However, most of the conclusions on this issue are rather speculative as, to date, few studies have been designed to specifically assess the recovery time after fishing disturbance (e.g. Kaiser et al., 1998; Frid et al., 2000; Gilkinson et al., 2003; Hiddink, 2003) and most of them concern short-term impacts (DeAlteries et al., 1999). Nevertheless, some studies have already showed some evidences of long-term persistency of negative effects on marine environment (e.g. Frid et al., 2000; Veale et al., 2000).

Areas closed to clam dredging have been used to study the effects of fishing in marine habitats. Therefore, for scientific purposes, in 2002 an exclusion zone of nearly $6 \mathrm{~km}^{2}$ located off Vale do Lobo (Algarve, southern Portugal) was closed to commercial fishing by dredge under national legislation. This area was selected in agreement with 
the fishing sector and was chosen because it was not fished for more than two years due to the collapse of the Spisula solida and Donax trunculus populations in that area. Such ground provided the adequate field conditions to carry out controlled experiments concerning the recovery periods of shallow dredged fishing grounds. In fact, in Portugal, several clam species are commercially exploited by the dredge fleet that operates mainly between 3 and $20 \mathrm{~m}$ depth. The present work aims to assess the effects of clam dredging and subsequent recovery in benthic habitats at different depths $(6 \mathrm{~m}$ and $18 \mathrm{~m})$ within the dredge fleet operational depth range.

\section{MATERIAL AND METHODS}

\subsection{Sampling strategy and laboratory analyses}

Field surveys were carried out in June (6m depth) and from August to October 2003 (18m depth) within the closed area (Fig. 1). Two areas, with approximately $2500 \mathrm{~m}^{2}$ (50m x 50m) each, were established. These areas were $\sim 0.9 \mathrm{~km}$ apart and $500 \mathrm{~m}$ from the closure edges, in order to guarantee the independence of samples and also the freedom from interference of nearby fishing operations. One of the areas was subjected to intense clam dredge-fishing (Impact area), while the other was undisturbed (Control area). During fishing, two clam dredges were towed simultaneously side-by-side for $2 \mathrm{~h}$ at a commercial towing speed of 2 knots. The dredges used in the present study were similar to the ones used by professional fishermen. This fishing gear weighs around $80 \mathrm{~kg}$ and is comprised of a metallic frame, a toothed lower bar (with tooth length of $20 \mathrm{~cm}$, spaced $2.2 \mathrm{~cm}$ ) at the dredge mouth (64 cm in length) and a rectangular metallic grid box (space between rods of $1.2 \mathrm{~cm}$ ) to retain the catch (detailed gear specification can be found in Gaspar et al., 
2003). Sampling strategy followed a BACI design, with both areas being sampled prior to fishing stress and after fishing stress. Samples of macrobenthos, meiobenthos and sediment were collected by SCUBA divers. For the shallower depth $(6 \mathrm{~m})$, samples were collected before (B), immediately after (IA), 1d, 3d and 17d after dredging. For 18m depth, samples were collected B, IA, 1d, 2d, 5d, 13d, 35d and 90d after dredging. The periodicity of sampling was established taking into account that recovery is hypothetically rapid immediately after impact and slower at deeper depths. Therefore sampling was intensified soon after the beginning of the experiments and extended longer at $18 \mathrm{~m}$. After fishing within the experimental sites, divers have chosen a clearly disturbed area where several dredge tracks were visible. These areas were marked with concrete blocks roped to a surface buoy. The centres of the control sites were also marked at the beginning of the experiment. The position of the buoys was taken with a Differential Global Positioning System (DGPS). The samples were collected randomly around the concrete blocks.

For the study of benthic communities three replicate samples were taken at each area and sampling occasion. In order to account for a patchy distribution of macro and meiobenthos organisms, each replicate was composed of 3 corer samples (total area per replicate of $0.02 \mathrm{~m}^{2}$ ) for macrofauna and 2 smaller core samples (total area per replicate of $0.002 \mathrm{~m}^{2}$ ) for meiofauna. Macrobenthos samples were retaining on a $500 \mu \mathrm{m}$ mesh sieve whereas the meiobenthos were sieved and retained on a $63 \mu \mathrm{m}$ mesh sieve. The retained material was fixed in $4 \%$ buffered formalin stained with Rose Bengal. Prior to identification, samples were washed and the organisms were hand sorted into major taxonomic groups, identified to the lowest practical taxonomic level (usually species level for macrofauna and a level higher than order for meiofauna) and counted. Taxonomic nomenclature followed MarBEF Data System 
(http://www.marbef.org/data/). For macrofauna, biomass expressed in ash-free dry weight (AFDW) was also determined for each taxa and per replicate.

Sediment particle size analysis was based on small corers (5cm i.d.; $20 \mathrm{~cm}$ depth). Each corer was opened, described and samples were analysed by standard sieving method (from $>2 \mathrm{~mm}$ to $<63 \mu \mathrm{m}$ ). Each fraction was dried and weighed and percentages determined. Grain-size parameters were computed by Folk and Ward (1957) method, using the Grangraf program (Carvalho, 1998).

\subsection{Data analysis}

Data was analysed using a combination of multivariate and univariate methods. Macro and meiobenthic community structure was analysed regarding abundance $(\mathrm{N})$, total number of taxa $(\mathrm{S})$, Margalef's species richness $(d)$, and diversity (ShannonWiener index $H^{\prime}, \log _{\mathrm{e}}$ ) indices. These variables were calculated for each area and sampling period.

In order to analyse the impacts of dredging on macrobenthic communities, several categories of different functional traits were assigned to the most abundant taxa following de Juan et al. (2007). We considered four biological traits: animal size $(<1$, $1-5,>5 \mathrm{~cm}$ ), body design (vermiform, scale or chitinous plates, shell), presence or absence of an external protection structure, and adult motility (sedentary, low motility and medium motility). Meiobenthic organisms were not analysed as functional traits as this faunal group was identified at high taxonomic levels.

Multivariate analyses were performed using the PRIMER v5.0 software package (Clarke and Gorley, 2001). For each sampling period, control and impacted areas were compared using one-way ANOVA. However, prior to ANOVA, data was tested 
for normality (Anderson Darling test) and homogeneity of variance (Bartlett's method) using SIGMASTAT. Whenever these assumptions were not met, the nonparametric test of Kruskal-Wallis (K-W) ANOVA on RANKS was used. Multiple comparison tests of Student Newman Keuls (S-N-K) were undertaken when null hypothesis was rejected. Similarity between areas and sampling periods was analysed by ordination techniques (non-metric MDS) based on the Bray-Curtis similarity coefficient after square-root transformation of the faunal data. The cluster analysis applied the group-average linkage method. One-way ANOSIM tests were used to test for differences in community structure (macro and meiofaunal data pooled) among areas for each sampling period using abundance data.

\subsection{Oceanographic setting}

Data regarding wave action within the sampling area was analysed in order to characterize the natural hydrodynamic disturbance to which the benthic communities were subjected during the study period.

Tides in the Algarve are semi-diurnal with mean amplitude of $2.8 \mathrm{~m}$ on spring tides and $1.3 \mathrm{~m}$ on neap tides. The wave climate is conditioned by the orientation of the coast which provides shelter from the dominant northwest swell generated in the North Atlantic, with mean significant wave height (Hs, defined as the average wave height - trough to crest - of the one-third largest waves) of $1 \mathrm{~m}$ and a direction predominantly from the W-SW (71\%) sector followed by the SE sector (23\%) (Costa et al., 2001). Wave data collected between 1986 and 2001 showed a strong seasonality, with an average number of storms (Hs $>3.5 \mathrm{~m})$ of 9.3 in winter (OctoberMarch) and 0.6 in summer (April-September). 
Offshore wave data for the surveying period was obtained from Faro wave buoy (maintained by the Portuguese Hydrographical Institute), located at the $80 \mathrm{~m}$ depth contour, off Cape Santa Maria (Fig. 2). During the experimental period, mainly low energy conditions $(\mathrm{Hs}<1 \mathrm{~m})$ were observed except for the periods ranging from the $9^{\text {th }}$ to the $20^{\text {th }}$ of June (i.e., between the $3 \mathrm{~d}$ and $17 \mathrm{~d}$ sampling for $6 \mathrm{~m}$ depth), where significant wave height exceeded $1.5 \mathrm{~m}$, reaching a maximum of $2.5 \mathrm{~m}$ (Fig. 2A). Major storm events were also recorded especially between $23^{\text {rd }}$ of October and $18^{\text {th }}$ of November (i.e. between 35 and $90 \mathrm{~d}$ for $18 \mathrm{~m}$ depth), with waves reaching 6 metres high (Fig. 2D).

\section{RESULTS}

\subsection{6m depth}

\subsubsection{Macrobenthos}

Abundance, number of taxa, diversity and species richness patterns for both areas and sampling periods are shown in Fig. 3. In general, no significant differences were detected between fished and control areas. Although not significant, the disturbed area usually presented lower values than the control area IA dredging, while at the remaining sampling periods, the reverse situation was observed (Fig. 3).

The analysis of the abundance changes within the impacted area after dredging for the taxa accounting for $80 \%$ of the total abundance is presented in Table 1. Five out of six taxa were considerably affected by dredging, as their abundance was reduced at least to $40 \%$ of the abundance observed before dredging (Urothoe sp.). In contrast, an unidentified nemertinean seemed to be positively affected by dredging, as its abundance increased (Table 1). The isopod Cirolana cranchii, the amphipod Urothoe 
sp. and an unidentified ophiuroid were the most affected. The latter was completely removed from the impacted area during the two first sampling periods after fishing (Table 1). All these taxa have scales or chitinous plates in their bodies, but in terms of the other functional traits analysed no consistency was found (Table 1).

\subsubsection{Meiobenthos}

Abundance, number of taxa, diversity and species richness did not show any significant differences between impacted and control areas during the sampling period (Fig. 4).

\subsubsection{Community structure}

The MDS plot for all community (macro and meiofauna) showed a separation between samples collected before and IA dredging within both control and impacted areas from the remaining. Therefore, no major impacts were detected (Fig. 5). The same pattern was observed concerning meiofauna samples, while the macrofaunal samples collected IA dredging within the impacted area were clearly separated in the MDS plot (Fig. 5).

No significant differences were detected by the ANOSIM test between control and impacted areas for any of the study periods $(\mathrm{p}>0.05)$.

\subsubsection{Sediment characterization}

Bottom sediments at the experiment site were mainly composed of fine sand (40$70 \%$ ) followed by medium and very fine sand. Coarser sand fractions represented less than $15 \%$. The impact of bottom dredging on the sediment is demonstrated by changes in the median grain-size ( $\phi$ units) computed for the control and dredged areas 
(Fig. 6). While in the control area there was not a clear change, in the dredged area there was a sudden decrease in the grain size immediately after dredging (the median increased from $2.2 \phi$ to $2.5 \phi$ ). This was followed by a slow increase and $17 \mathrm{~d}$ after dredging, the median in both areas became quite similar, slightly coarser than $2.2 \phi$ (Fig. 6).

\section{2. $18 \mathrm{~m}$ depth}

\subsubsection{Macrobenthos}

The impacted area showed significantly lower abundance, number of taxa and Shannon-Wiener diversity (ANOVA, p<0.05) IA dredging in comparison to the control area (Fig. 7). For some of the measures, similar results were detected after 5 (S) and 90 days after dredging (N, S, $\left.H^{\prime}\right)$ (Fig. 7).

Although most of the taxa were noticeably affected by dredging, an unidentified Eunicidae, Goniadella sp., Parapionosyllis sp. and Lumbrineriopsis sp. were added to the community as they were sampled only after dredging and persisted in it as they were consistently sampled thereafter (Table 2). Within the taxa enhanced by fishing, polychaetes with vermiform shape, without external protection, and carnivory were the dominant functional categories (Table 2). Concerning the taxa negatively affected by dredging, they were mostly crustaceans (mainly amphipods) and polychaetes. The most affected functional categories were the animals that had scales or chitinous bodies, vermiform shape, absence of external protection and deposit-feeding mode (Table 2).

\subsubsection{Meiobenthos}


According to these results, dredging seems to have caused a decrease in meiofauna abundance and number of taxa that persisted until 13 to 35 days (Fig. 8). This decrease although not significant was more evident for abundance (Fig. 8).

\subsubsection{Community structure}

Considering both the entire community and also the meiofauna analysed separately, the negative effect of dredging in the benthic community is discernible as most of the samples from the impacted area were separated from the remaining. However, 35d after dredging the impacts were no longer detected (Fig. 9). Macrofaunal data did not show this clear effect (Fig. 9).

No significant differences were detected by ANOSIM tests between control and impacted areas for any of the study periods $(\mathrm{p}>0.05)$.

\subsubsection{Sediment characterization}

Bottom sediments were dominated by coarse sand and gravel fractions. These fractions represented usually more than $80 \%$ of the entire sample, while finer fractions

(fine, very fine sand and $>4 \phi$ sediments) rarely exceed $2 \%$. Sediment was moderately sorted with a median corresponding to coarse and very coarse sand.

Within the study area, samples collected before dredging were characterized by a mean median grain-size of $0.00 \phi$ (median grain-size values ranged between $-0.25 \phi$ and $0.34 \phi$ ) (Fig. 10). Immediately after dredging, sediment was found to be slightly coarser $(0.05 \phi)$, ranging within a similar interval (from $-0.22 \phi$ and $0.21 \phi)$ (Fig. 10). One day after dredging, a major change in sediment grain-size was recorded in the impacted area, as sediment became coarser than the previous samples $(-0.45 \phi)$ (Fig. 
10). Afterwards, and until 13 days after dredging, the sedimentary record showed a gradual trend to become slightly finer (median mean: $-0.3 \phi$, maximum: $0.11 \phi$; minimum: $-0.67 \phi$ ) (Fig. 10). From that period onwards, samples showed the same textural pattern with minor fluctuations in median grain-size (mean of $-0.06 \phi$ and $0.04 \phi$ for 35 and 90 days after dredging, respectively), revealing a similar textural pattern to the one observed at the beginning of the experience (Fig. 10). During the extent of the experiment, in the control area, sediment median showed a relatively constant pattern with only minor fluctuations (max: 0.34 to $-0.13 \phi$; min: 0.19 to 0.31ф; mean: 0.21 to $-0.06 \phi$ ) (Fig. 10). These fluctuations became more evident 2 days and 35 days after dredging, where all collected samples corresponded to medium sand (Fig. 10).

\section{DISCUSSION}

\section{Biological impacts}

The present study showed that dredging impacts on benthic communities seem to be depth dependent. Moreover, depending on the faunal component used as bioindicator, different results can be observed.

In general, no clear impacts were observed for the shallower area either considering univariate and multivariate methods and also macro and meiofaunal data. Despite the lack of clear differences between control and dredged areas, a general decrease in abundance of the most abundant taxa was observed after dredging. Regarding $18 \mathrm{~m}$ depth, the results of this study clearly demonstrated that clam dredging causes an immediate effect on the meio- and macrobenthic communities. Considering 
macrofauna, all biological variables showed a significant decrease immediately after dredging, probably due to the removal of target and non-target species by the gear and/or spatial redistribution of macrobenthic fauna in the dredged area (Hiddink, 2003). Several authors described similar results for different kinds of bottom fishing gears. For example, Pranovi et al. (2004) in a multidisciplinary study of the immediate effects of mechanical clam harvesting in the Venice lagoon detected a significant decrease in the total number of individuals after the haul. Thrush et al. (1995) observed a decrease in macrofaunal taxa due to scallop dredging and Kaiser and Spencer (1996) reported a general decrease in biodiversity after beam trawling. Biodiversity loss may persist over long periods of time, namely due to the reduction of habitat complexity, resulting from the removal of tubicolous organisms and epibenthic species (Dayton et al., 1995; Kaiser et al., 2000). These organisms are particularly important as they provide protection for commercial species, and their removal will potentially affect fisheries (Kaiser et al., 2000).

Most fishing impact studies focused only on changes of macrofauna, whereas smaller benthic components have been largely neglected. Since meiofauna are among the smallest animals in benthic communities and have very fast turnover times, they may be expected to show little or no response to dredging (Schratzberger et al., 2002). In fact, such absence of significance and/or sensitivity to mobile gear-driven changes of meiobenthos when compared with macrobenthos has also been noted by other authors (e.g.: Schratzberger et al., 2002; Pranovi et al., 2004). Nevertheless, in the present study multivariate analyses performed with both macro- and meiofaunal data showed that the latter may have higher sensitivity to dredging impacts. While for macrofauna, dredging impacts were only apparent IA fishing, for meiofauna these impacts were 
detected until $35 \mathrm{~d}$ after dredging. Therefore, the detection of benthic impacts may be hampered by the faunal component used during a monitoring study.

In general, the most affected taxa had bodies both with scales or chitinous plates and vermiform shape especially crustaceans, polychaetes and ophiuroids. Moreover, most of these taxa did not have external protection but were mainly deposit-feeders. In contrast, some polychaete taxa without external protection and with a carnivorous feeding mode were enhanced by fishing. Shifts in dominance of feeding modes have been extensively described in relation to commercial fisheries (Lindeboom and de Groot 1998, Jennings et al. 2001). The passage of the dredge across the sediment floor will kill or injure some organisms that will then be exposed to potential predators/scavengers (Frid et al. 2000, Veale et al. 2000). Therefore, the enhancement of carnivore taxa after dredging is not surprising. The persistence of disturbance will benefit these opportunistic organisms, increasing their abundance (Frid et al. 2000) and potentially changing the trophic structure of the benthic communities.

\section{Impact on the sediment}

The analysis of bottom sediment grain-size data suggested that dredge fishery impacts both sediment morphology and texture. The passage of the dredge on the bottom produced a slightly depressed track, about $30 \mathrm{~cm}$ wide and $10 \mathrm{~cm}$ depth, where the sedimentary structures were disrupted. Previous studies (e.g. Watling et al., 2001; Tuck et al., 2000) reported that the dredging activities tend to induce the resuspension of fine-grained particles thus resulting in sediment coarsening. This effect was not consistently observed in the present study. In fact, within the shallower area $(6 \mathrm{~m}$ depth experiment) the measured textural differences were relatively small, with a slight decrease (increase in phi units) in the mean grain-size immediately after 
dredging. Nevertheless, the observed changes are within bottom sediment variability. After 17 days, differences between control and dredged areas were minimal. On the other hand, at 18m depth, 1day after dredging, a slight increase in grain size was detected within the dredged area. This result might be related to the subsequent infilling of the dredge tracks by coarse particles that were dislodged to the sides of the trench during dredging (Caddy, 1973; Eleftheriou and Robertson, 1992; Currie and Parry, 1999). Subsequently, there was a progressive increase in gravel content, which reduced the differences between control and dredged areas; after 13 days, mean sediment grain size in the disturbed area was similar to the undisturbed sediments in deeper waters.

The low level of perturbations induced by the dredging activities can be related to a multiplicity of factors. In a wave-dominated environment, like the one examined in the study, this effect might be essentially related with the activity of surface waves on the bottom. If wave time-series are compared to the changes in benthic fauna, it becomes clear that the most significant changes were related to the more energetic events, which occurred between the $9^{\text {th }}$ and the $20^{\text {th }}$ of June and between the $23^{\text {rd }}$ of October and the $18^{\text {th }}$ of November, and masking fishing effects. The highly dynamic nature of this environment can be demonstrated by the wave orbital velocities that affect the bottom. For example, for the shallow water areas (average depth of $8 \mathrm{~m}$ ), considering a significant wave height of $1 \mathrm{~m}$ with a period of $5 \mathrm{~s}$, linear wave theory (e.g. Dean and Dalrymple, 1991) predicts a maximum orbital bottom velocity of $0.29 \mathrm{~m} \mathrm{~s}^{-1}$, which exceed the Hallermeier (1980) threshold for $500 \mu \mathrm{m}$ quartz particles. These results showed that at $6 \mathrm{~m}$ depth, sediments were mobile during a large part of the experiment, which may explain the fast recovery recorded for the sediment and for benthic communities. Sediments from deeper areas were also affected by storm 
events. Using linear wave theory maximum bottom orbital velocities at the $18 \mathrm{~m}$ contour were computed from deepwater wave parameters recorded by the wave buoy located near the study area. At the beginning of the experiment, energy levels at the bottom were relatively weak $\left(<0.08 \mathrm{~m} \mathrm{~s}^{-1}\right)$. Between the 5 and 13 days after dredging and during a large part of October, there were major gaps in available wave data, thus preventing estimates of bottom energy levels during these periods. Significant bottom sediment mobility was only observed after mid September and particularly during the $25^{\text {th }}$ to $29^{\text {th }}$ October storm where bottom orbital velocities attained $1.39 \mathrm{~m} \mathrm{~s}^{-1}$ and exceeded the threshold criteria for the entire sedimentary spectrum.

From these considerations it can be inferred that the initial sediment textural changes for the $18 \mathrm{~m}$ depth experiment should have been essentially gravity driven (i.e. related to the morphological disturbance of the dredging activities) as bottom energy levels were insufficient to move most of sedimentary particles. This process should have a very limited spatial and temporal scope, and therefore might have played a minor role in the overall recovery of the disturbed area. The significant recovery observed from 5 days to 13 days after dredging, can be related to an increase in bottom energy levels partially represented in the data (unfortunately there is a gap in wave period data between the $25^{\text {th }}$ and $31^{\text {st }}$ August) and can explain the relative increase in the finer sand fractions. After 13 days, several high energy events were observed which induced bottom orbital velocities exceeding the threshold of the entire grain-size spectrum and therefore easily masking the sedimentary perturbation induced by the dredging activities.

The relationship between depth and benthic impacts 
In the present study, the relationship between depth and fishing impacts seemed to be highly dependent on the ecosystem characteristics, namely wave action. For instance, when considering sediments and macrobenthic fauna, an apparent immediate effect of fishing disturbance can be recorded, but a considerably faster recovery of macrobenthos was observed within the shallower area. According to several studies, macrobenthic communities from high-energy environments tend to be less affected to fishing as they are naturally and consistently subjected to disturbance (e.g. Currie and Parry, 1996; Kaiser et al., 1996; Zajac and Whitlatch, 2003). Nevertheless, in a moderately disturbed environment, Morello et al. (2006) found that fishing impacts on benthic community structure were still distinguishable from those resulting from natural variation. Therefore, the frequency and intensity of environmental disturbances such as storms may be among the key factors determining the resilience of the benthic community to fishing (Morello et al., 2006). Conversely, with depth increase the frequency and intensity of natural disturbance events tend to decrease. This will result in more stable environments with communities that are usually less resilient to environmental changes.

The vulnerability of the sampling area to wave action appears to be corroborated by the visual recognition of the dredge track, which, in this study, was not apparent 24 hours after dredging at $6 \mathrm{~m}$ depth. On the other hand, at $18 \mathrm{~m}$ depth, tracks were still visible 13 days after dredging. Thus, oceanographic forcing can also be responsible for differences observed in macro- and meiobenthos. The occurrence of major storm events recorded especially between the last two sampling surveys for the $18 \mathrm{~m}$ depth areas appeared to produce greater changes in macrobenthic communities than the fishing operations, as samples from control and impact area were distinct from the remaining samples. In fact, the effect of wave action has been previously suggested as 
a forcing function for the restoration and recovery of fisheries-disturbed grounds (Kaiser et al., 1998; DeAlteris et al., 1999; Gaspar et al., 2003; Flåten et al., 2004). It has been reported that the effects of storms may be much greater that anthropogenic stress (Hall et al., 1990; Brylinsky et al., 1994; Dolmer and Frandsen, 2002). Moreover, animals adapted to highly dynamic seabed environment are more resistant to disturbance (Boesch and Rosenberg, 1981) and may actually not be affected by fishing gears (DeAlteris et al., 1999). Furthermore, the short-lived track configuration also reinforces the importance of wave action and currents on the habitat restoration, as previously suggested by Gaspar et al. (2003) also studying Portuguese clam-dredge fishing effects.

\section{CONCLUSIONS}

From the present case study, it can be assumed that clam-dredging activity disturbs the seabed, but the significance of that disturbance can be compared in magnitude and frequency to natural seabed disturbances. In fact, bottom energy levels at these depths, particularly during storms, are relatively high and may be responsible for the relatively rapid elimination of the morphological and sedimentary impact related to the dredging activities. This study was only possible due to the existence of a similar unexploited area (control) that had been closed to dredging since 2002 and where natural temporal changes could be studied. The absence of a suitable control area has been highlighted as a major constraint in similar studies. In most cases, such works have been undertaken in areas already modified by bottom fishing gears, and consequently benthic communities remaining in these areas are generally impoverished and resilient to fishing (Currie and Parry, 1996, Tuck et al., 1998). 
Thus, we uphold the statement of DeAlteris et al. (1999), arguing that the relative significance of dredge fishery-driven disturbance should be scaled against the magnitude and frequency of natural habitat-stressing phenomena. Notwithstanding, care must be taken, as causal relationships between biological and environmental variables are not straightforward (Flåten et al., 2004).

Future management strategies for subtidal highly hydrodynamic fishing grounds should consider alternatives to permanently closed areas given the considerably fast recovery of communities, associated with the apparent ability for organisms to cope with physical stress of greater magnitude. Nevertheless, more studies are needed namely on the impacts caused by long-term cumulative fishing stress.

\section{ACKNOWLEDGEMENTS}

We would like to thank the crews of the RV "Donax" and the Fishing Vessel "Família Santa" for their skilful help. This study was conducted within the "DREDIMPACT" project (POCTI MGS-42319/2001). The authors thank to Pedro Fernandes, Selma Gabriel and Sílvia Serina for their helpful contribution for the laboratory grain-size analysis. Thanks are due to the referees for the constructive comments that significantly improved the manuscript.

\section{REFERENCES}

Boesch, D.F., Rosenberg, R., 1981. Response to stress in marine benthic communities. In: Barret, G.W., Rosenberg, R. (Eds). Stress effects on natural ecosystems. J. Wiley \& Sons, New York, pp. 179-200. 
Caddy, J.F., 1973. Underwater observations on track dredges and trawls and some effects of dredging on a scallop grounds. Journal of the Fisheries Research Board of Canada 30, 173-180.

Carbines, G., Jiang, W., Beentjes, M.P., 2004. The impact of oyster dredging on the growth of blue cod, Parapercis colias, in Foveaux Strait, New Zealand. Aquatic Conservation: Marine and Freshwater Ecosystems 14(5), 491-504.

Carvalho, C.M.N., 1998. Programa para tratamento de dados granulométricos GRANGRAF V2.08, FCUL, Lisboa.

Bordehore, C.C., Ramos-Esplá, A.A., Riosmena-Rodríguez, R., 2003. Comparative study of two maerl beds with different otter trawling history, southeast Iberian Peninsula. Aquatic Conservation: Marine and Freshwater Ecosystems 13(S1), S43-S54.

Clarke, K.R., 1990. Comparisons of dominance curves. Journal of Experimental Marine Biology and Ecology 138, 143-157.

Clarke, K.R, Gorley, R.N., 2001. PRIMER (Plymouth Routines In Multivariate Ecological Research) v5: User Manual/Tutorial. Primer-E Ltd, Plymouth. 91pp.

Collie, J., Hall, S.J., Kaiser, M.J., Poiner, I.R., 2000. A quantitative analysis of fishing impacts on shelf-sea benthos. Journal of Animal Ecology 69, 785-798.

Costa, C.L., 1994. Final report of sub-project A "Wind wave climatology of the Portuguese Coast". Report 6/94-A. Instituto Hidrográfico/LNEC, Lisboa, 80 pp.

Costa, M., Silva, R., Vitorino, J., 2001. Contribuição para o estudo do clima de agitação marítima na costa portuguesa. $2^{\text {as }}$ Jornadas de Engenharia Costeira e Portuária, AIPCN, 20 pp (in CD-ROM). 
Cranfield, H.J., Michael, K.P., Doonan, I.J., 1999. Changes in the distribution of epifaunal reefs and oysters during 130 years of dredging for oysters in Foveaux Strait, southern New Zealand. Aquatic Conservation: Marine and Freshwater Ecosystems 9, 461-483.

Currie, D.R., Parry, G.D., 1996. Effects of scallop dredging on a soft sediment community: a large experimental study. Marine Ecology Progress Series 134, $131-150$

Currie, D.R., Parry, G.D., 1999. Changes to benthic communities over 20 years in Port Phillip Bay, Victoria, Australia. Marine Pollution Bulletin 38, 36-43.

DeAlteris, J., Skrobe, L., Lipsky, C., 1999. The significance of seabed disturbance by mobile fishing gear relative to natural processes: a case study in Narragansett Bay, Rhode Island. In: Benaka LR (Eds) Fish Habitat: Essential fish habitat and rehabilitation. American Fisheries Society, Symposium 22, Bethesda, Maryland.

Dean, R., Dalrymple, R.A., 1991. Water Wave Mechanics for Engineers and Scientists, World Scientific Publishing.

de Juan, S., Thrush. S.F., Demestre, M. 2007. Functional changes as indicators of trawling disturbance on a benthic community located in a fishing ground (NW Mediterranean Sea). Marine Ecology Progress Series 334, 117-129.

Dolmer, P., Frandsen, R., 2002. Evaluation of the Danish mussel fishery: suggestions for an ecosystem management approach. Helgoland Marine Research 56 (1), $13-20$.

Eleftheriou, A., Robertson, M.R., 1992. The effects of experimental scallop dredging on the fauna physical environment of a shallow sandy community. Netherlands Journal of Sea Research 30, 289-299. 
Flåten, G.R., Botnen, H., Grung, B., Kvalheim, O.M., 2004. Assigning environmental variables to observed biological changes. Analytical and Bioanalytical Chemistry 380, 453-466.

Folk, R.L., Ward, W.C., 1957. Brazos River bar: a study in the significance of grain size parameters. Journal of Sedimentary Petrology 27, 3-26.

Frid, C.L.J., Harwood, K.G., Hall, S.J., Hall, J.A., 2000. Long-term changes in the benthic communities on North Sea fishing grounds. ICES Journal of Marine Science 57, 1303-1309.

Gaspar, M.B., Santos, M.N., Leitão, F., Chícharo, L., Chícharo, A. Monteiro, C.C., 2003. Recovery of substrates and macro-benthos after fishing trials with a new Portuguese clam dredge. Journal of Marine Biological Association U.K. 83, 713-717.

Gilkinson, K.D., Fader, G.B.J, Gordon Jr, D.C., Charron, R., Mckeown, D., Roddick, D., Kenchington, E.L.R., MacIsaac, K., Bourbonnais, C., Vass, P., Liu, Q., 2003. Immediate and longer-term impacts of hydraulic clam dredging on an offshore sandy seabed: effects on physical habitat and processes of recovery. Continental Shelf Research 23, 1315-1336.

Gray, S.J., 1989. Effects of environmental stress on species rich assemblages. Biological Journal of the Linnean Society 37, 19-32.

Groenewold, S., Fonds, M., 2000. Effects on benthic scavengers of discards and damaged benthos produced by the beam-trawl fishery in the southern North Sea. ICES Journal of Marine Science 57, 1395-1406.

Gutiérrez, J.L., Palomo, M.G., Iribarne, O.O., 2004. Environmental heterogeneity and species responses to fishing disturbance: are the effects of clam harvesting spatially consistent? Fisheries Research 67 (1), 55-70. 
Hallermeier, R.J., 1980. Sand motion initiation by water waves. Two asymptotes. J. Waterway, Port Coastal and Ocean Div., ASCE, 106, 299-318.

Hall, S.J., Basford, D.J., Robertson, M.R., 1990. The impact of hydraulic dredging for razor clams Ensis sp. on an infaunal community. Netherlands Journal of Sea Research 27, 119-125.

Hall-Spencer, J.C., Froglia, C., Atkinson, R.J.A., Moore, P.G., 1999. The impact of Rapido trawling for scallops, Pecten jacobaeus (L.), on the benthos of the Gulf of Venice. ICES Journal of Marine Science 56, 111-124.

Hall-Spencer, J.M., Moore, P.G., 2000. Scallop dredging has profound, long-term impacts on maerl habitats. ICES Journal of Marine Science 57, 1407-1415.

Hall-Spencer, J.M., Grall, J., Moore, P.G., Atkinson, R.J.A., 2003. Bivalve fishing and maerl-bed conservation in France and the UK - retrospect and prospect. Aquatic Conservation: Marine and Freshwater Ecosystems 13 (S1), S33-S41.

Hiddink, J.G., 2003. Effects of suction-dredging for cockles on non-target fauna in the Wadden Sea. Journal of Sea Research 50, 315-323.

Jennings, S., Pinnegar, J.K., Polunin, V.C., Warr, K.J., 2001. Impacts of trawling disturbance on the trophic structure of benthic invertebrate communities. Marine Ecology Progress Series 213, 127-142.

Kaiser, M.J., Spencer, B.E., 1996. The effects of beam-trawl disturbance on infaunal communities in different habitats. Journal of Animal Ecology 65, 1-25.

Kaiser, M.J., Edwards, D.B., Armstrong, P.J., Radford, K., Lough, N.E.L., Flatt, R.P., Jones, H.D., 1998. Changes in megafaunal benthic communities in different habitats after trawling disturbance. ICES Journal of Marine Science 55, 353361. 
Kaiser, M.J., Ramsay, K., Richardson, C.A., Spence, F.E., Brand, A.R., 2000. Chronic fishing disturbance has changed shelf sea benthic community structure. Journal of Animal Ecology 69, 494-503.

Lindeboom, H.J., de Groot, S.J., 1998. The effects of different types of fisheries on the North Sea and Irish Sea benthic ecosystems: NIOZ Rapport 1998-1. Netherlands Institute for Sea Research (NIOZ), Texel.

Morello, E.B., Froglia, C., Atkinson, R.J.A., Moore, P.G., 2006. Medium-term impacts of hydraulic clam dredgers on a macrobenthic community of the Adriatic Sea (Italy). Marine Biology 149, 401-413.

Pranovi, F., Da Ponte, F., Raicevich, S., Giovanardi, O., 2004. A multidisciplinary study of the immediate effects of mechanical clam harvesting in the Venice Lagoon. ICES Journal of Marine Science 51, 43-52.

Schratzberger, M., Dinmore, T., Jennings, S., 2002. Impacts of trawling on the diversity, biomass and structure of meiofauna assemblages. Marine Biology $140(1), 83-93$.

Thrush, S., Hewitt, J., Cummings, V., Dayton, P., 1995. The impact of habitat disturbance by scallop dredging on marine benthic communities: What can be predicted from the results of experiments? Marine Ecology Progress Series $129,141-150$.

Tuck, I.D., Hall, S.J., Robertson, M.R., Armstrong, M.R., Basford, D.J., 1998. Effects of physical trawling disturbance in a previously unfished Scottish Sea Loch. Marine Ecology Progress Series 162, 227-242.

Tuck, I.D., Baylei, N., Harding, M., Sangster, G., Howell, T., Graham, N., Breen, M., 2000. The impact of Water-jet dredging for razor clam dredging, Ensis spp, in a shallow sandy subtidal environmental. Journal of Sea Research 43: 65-81. 
Veale, L.O., Hill, A.S., Hawkins, S.J., Brand, A.R., 2000. Effects of long-term physical disturbance by commercial scallop fishing on subtidal epifaunal assemblages and habitats. Marine Biology 137, 325-337.

Watling, L., Findlay, R.H., Mayer, L.M. Schick, D.F., 2001. Impact of a scallop drag on the sediment chemistry, microbiota, and faunal assemblages of a shallow subtidal marine benthic community. Journal of Sea Research 46 (3-4), 309324. 
Figure captions

Figure 1. Southern coast of Portugal (Algarve). Location of the study areas.

Figure 2. Wave height recorded during the sampling period. A $-6 \mathrm{~m}$ depth experiment. B to D - 18m depth experiment. Dark lines - maximum wave height; light gray lines - significant wave height; circled dates represent sampling occasions.

Figure 3. Variation of mean abundance $\left(\mathrm{N}\right.$, ind $\left.\times 0.02 \mathrm{~m}^{-2}\right)$, number of taxa $(\mathrm{S}$, $\left.\operatorname{taxa} \times 0.02 \mathrm{~m}^{-2}\right)$, species richness $(d)$ and diversity $\left(H^{\prime}\right)$ for macrobenthic communities from $6 \mathrm{~m}$ depth $(*$ - statistical significant differences $\mathrm{p}<0.05)$. B - before; IA immediately after; $\mathrm{d}$ - days after dredging. Vertical lines represent standard deviation.

Figure 4. Variation of mean abundance $\left(\mathrm{N}\right.$, ind $\left.\times 0.002 \mathrm{~m}^{-2}\right)$, number of taxa $(\mathrm{S}$, $\left.\operatorname{taxa} \times 0.002 \mathrm{~m}^{-2}\right)$, species richness $(d)$ and diversity $\left(H^{\prime}\right)$ for meiobenthic communities from $6 \mathrm{~m}$ depth $(*$ - statistical significant differences $\mathrm{p}<0.05)$. B - before; IA immediately after; $\mathrm{d}$ - days after dredging. Vertical lines represent standard deviation.

Figure 5. Multidimensional scaling ordination diagrams for all community, macrofauna and meiobenthic data, at $6 \mathrm{~m}$ depth. B - before; IA - immediately after; $\mathrm{d}$ days after dredging. White circles - control samples; black circles - impact samples.

Figure 6. Median grain-size variations in the control and impact areas for $6 \mathrm{~m}$ depth during sampling period. Bars represent samples' average grain-size and vertical lines minimum and maximum values. B - before; IA - immediately after; $\mathrm{d}$ - days after dredging.

Figure 7. Variation of mean abundance $\left(\mathrm{N}\right.$, ind $\left.\times 0.02 \mathrm{~m}^{-2}\right)$, number of taxa $(\mathrm{S}$, taxa $\times 0.02 \mathrm{~m}^{-2}$ ), species richness $(d)$ and diversity $\left(H^{\prime}\right)$ for macrobenthic communities from $18 \mathrm{~m}$ depth $(*$ - statistical significant differences $\mathrm{p}<0.05)$. B - before; IA immediately after; $\mathrm{d}$ - days after dredging. Vertical lines represent standard deviation. 
Figure 8. Variation of mean abundance $\left(\mathrm{N}\right.$, ind $\left.\times 0.002 \mathrm{~m}^{-2}\right)$, number of taxa $(\mathrm{S}$, $\left.\operatorname{taxa} \times 0.002 \mathrm{~m}^{-2}\right)$, species richness $(d)$ and diversity $\left(H^{\prime}\right)$ for meiobenthic communities from $18 \mathrm{~m}$ depth $\left(^{*}\right.$ - statistical significant differences $\left.\mathrm{p}<0.05\right)$. B - before; IA immediately after; d - days after dredging). Vertical lines represent standard deviation.

Figure 9. Multidimensional scaling ordination diagrams for all community, macrofauna and meiobenthic data at $18 \mathrm{~m}$ depth. B - before; IA - immediately after; $\mathrm{d}$ - days after dredging. White circles - control samples; black circles - impact samples.

Figure 10. Median grain-size variations in the control and impact areas for $18 \mathrm{~m}$ depth during sampling period. Bars represent samples' average grain-size and vertical lines minimum and maximum values. B - before; IA - immediately after; $\mathrm{d}$ - days after dredging. 
Fig.1

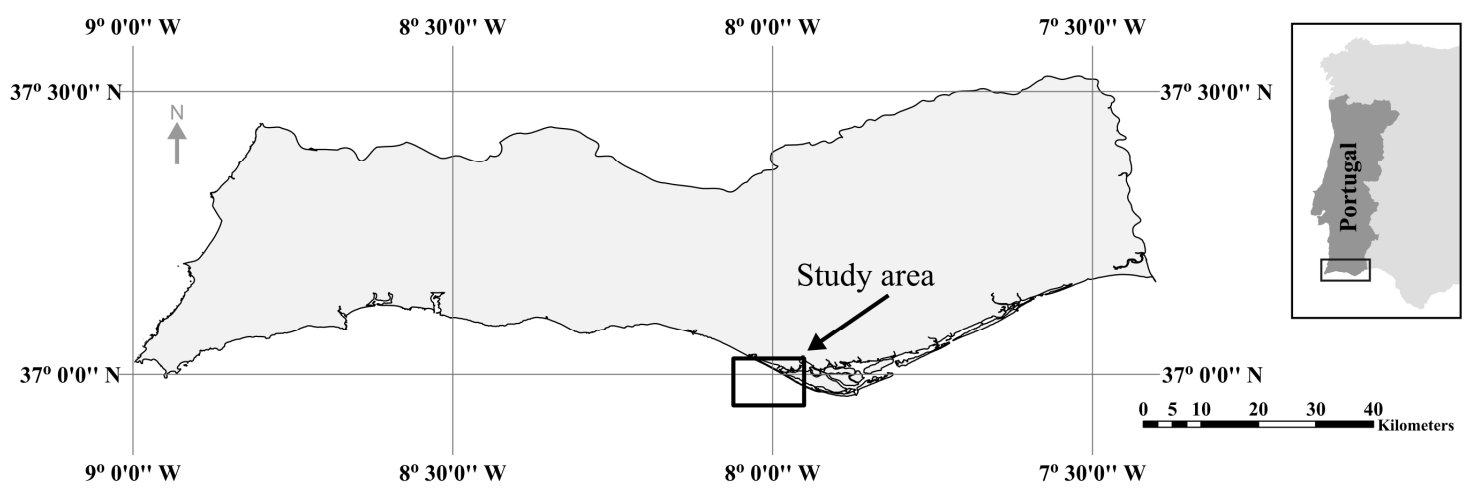


Fig. 2
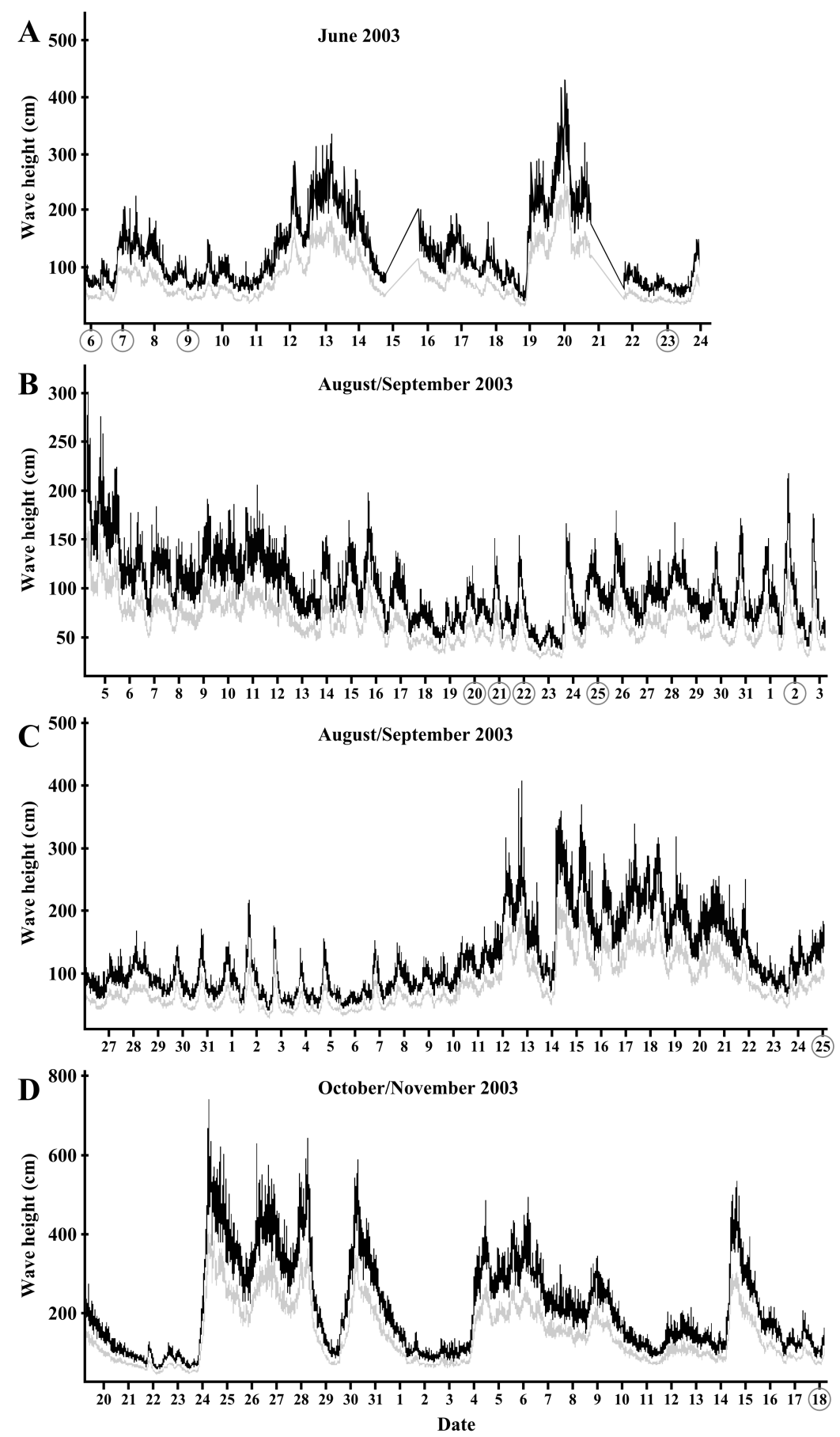


\section{ACCEPTED MANUSCRIPT}

Fig.3
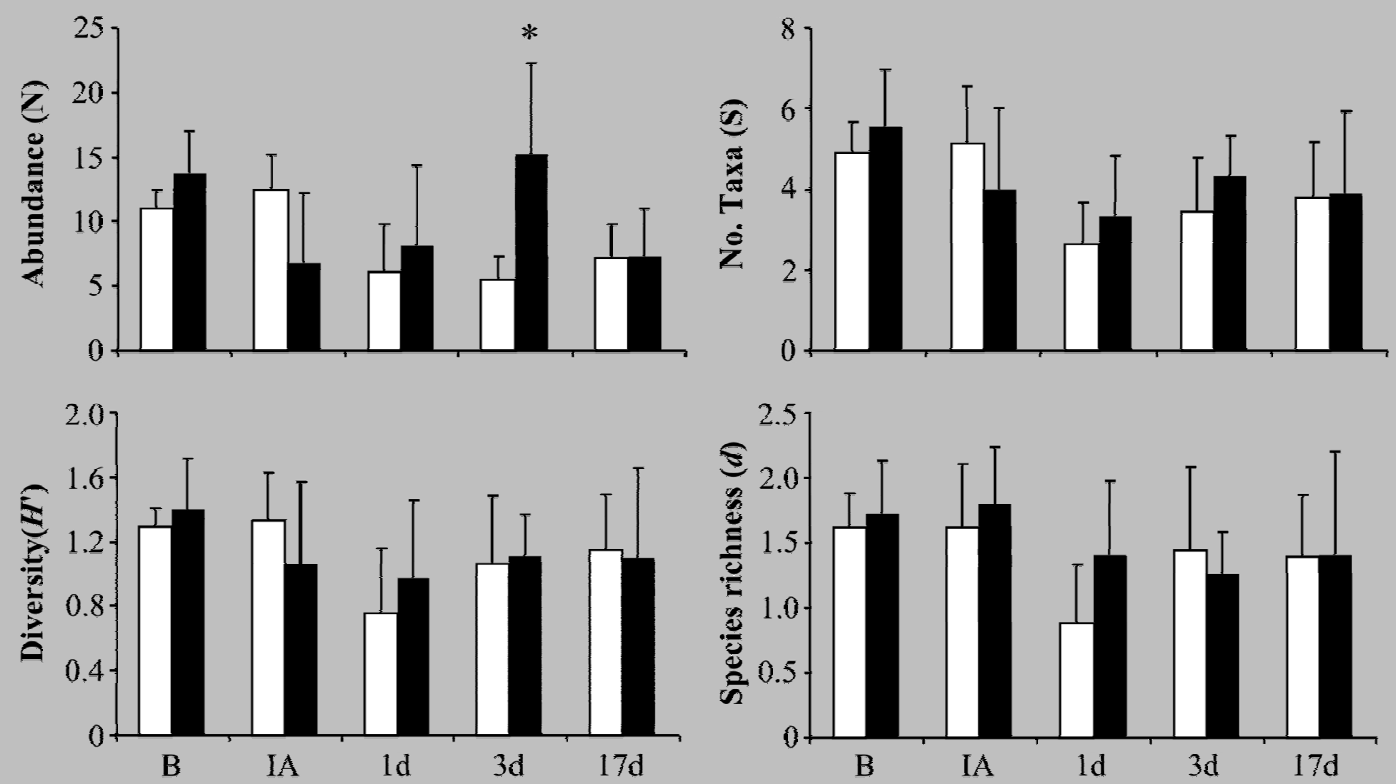

$\square$ Control $\square$ Impact 


\section{ACCEPTED MANUSCRIPT}

Fig.4
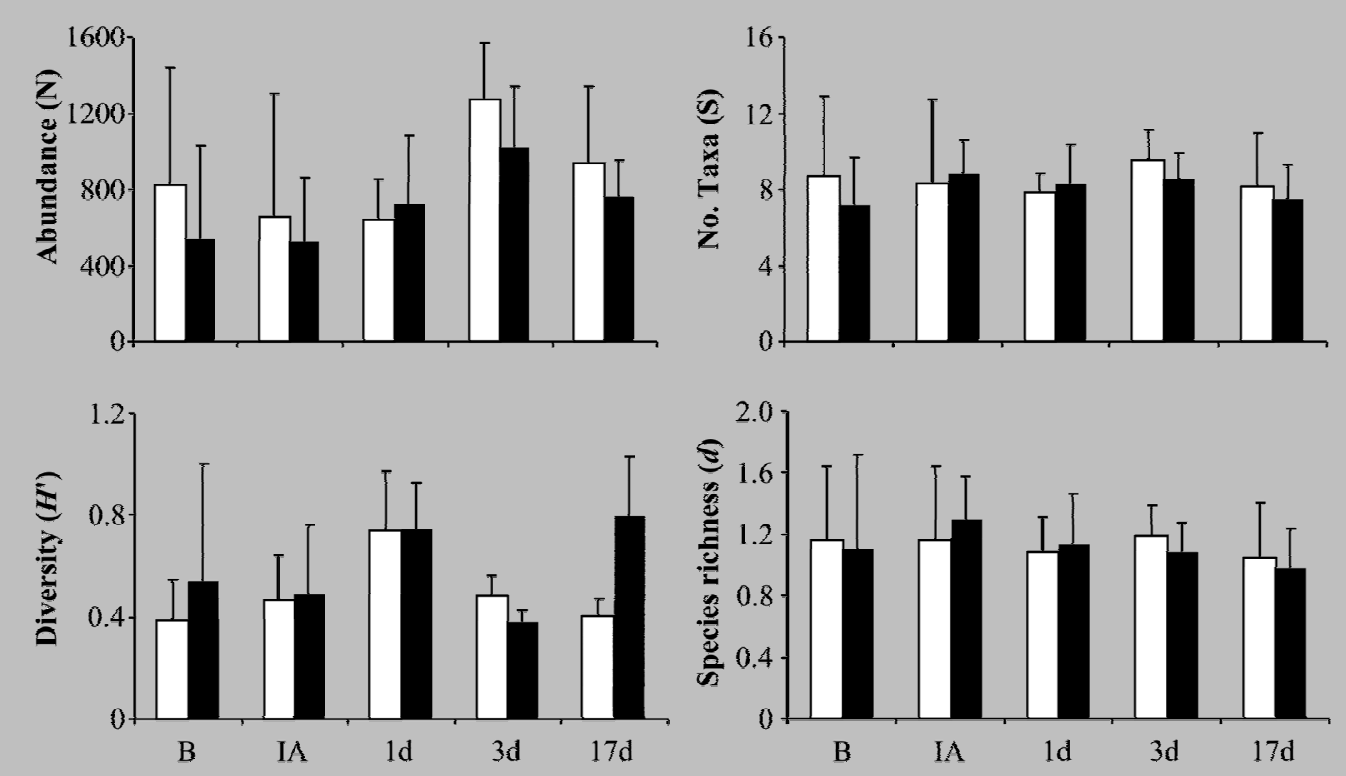

$\square$ Control $\square$ Impact 


\section{ACCEPTED MANUSCRIPT}

Fig.5

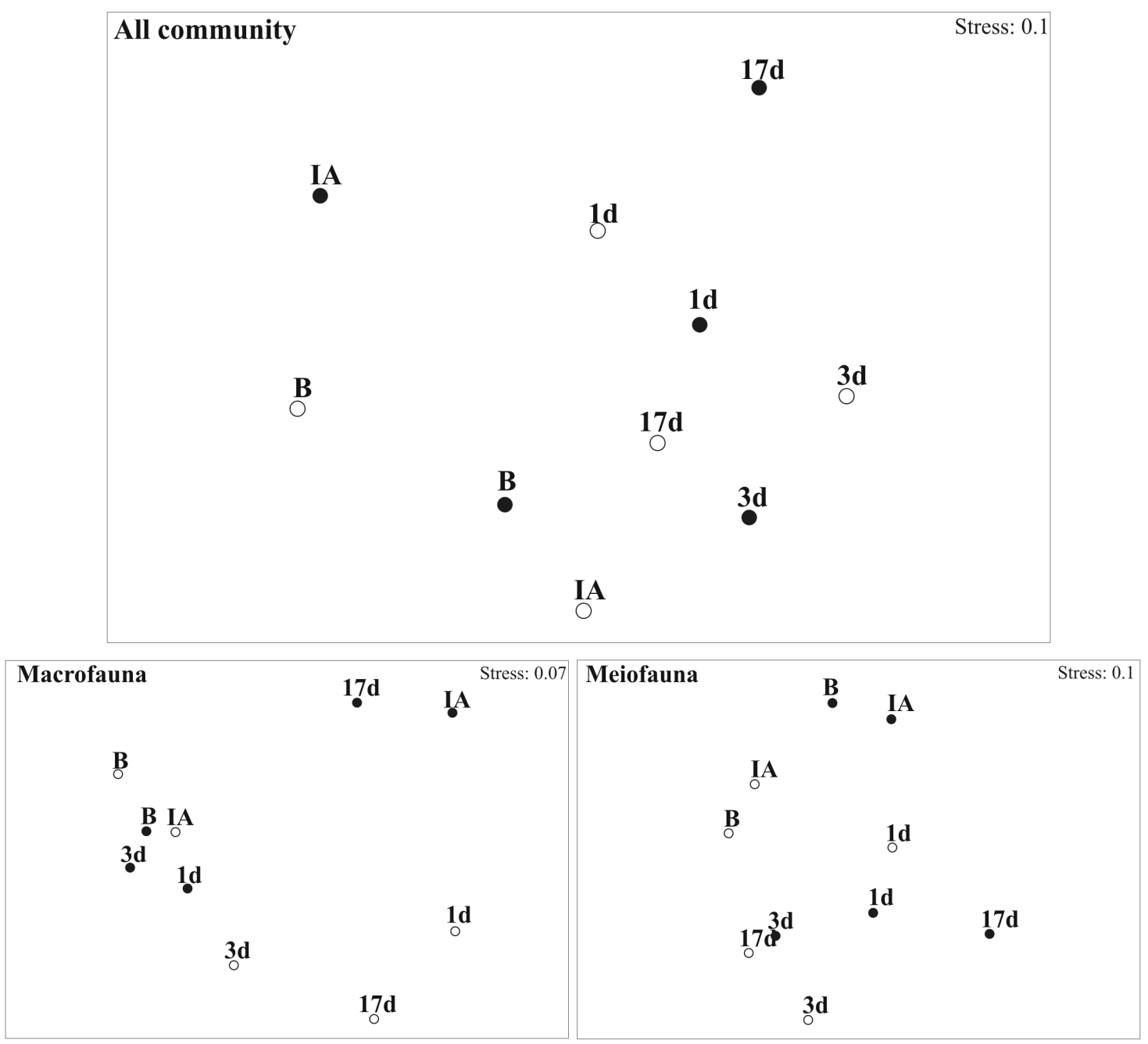




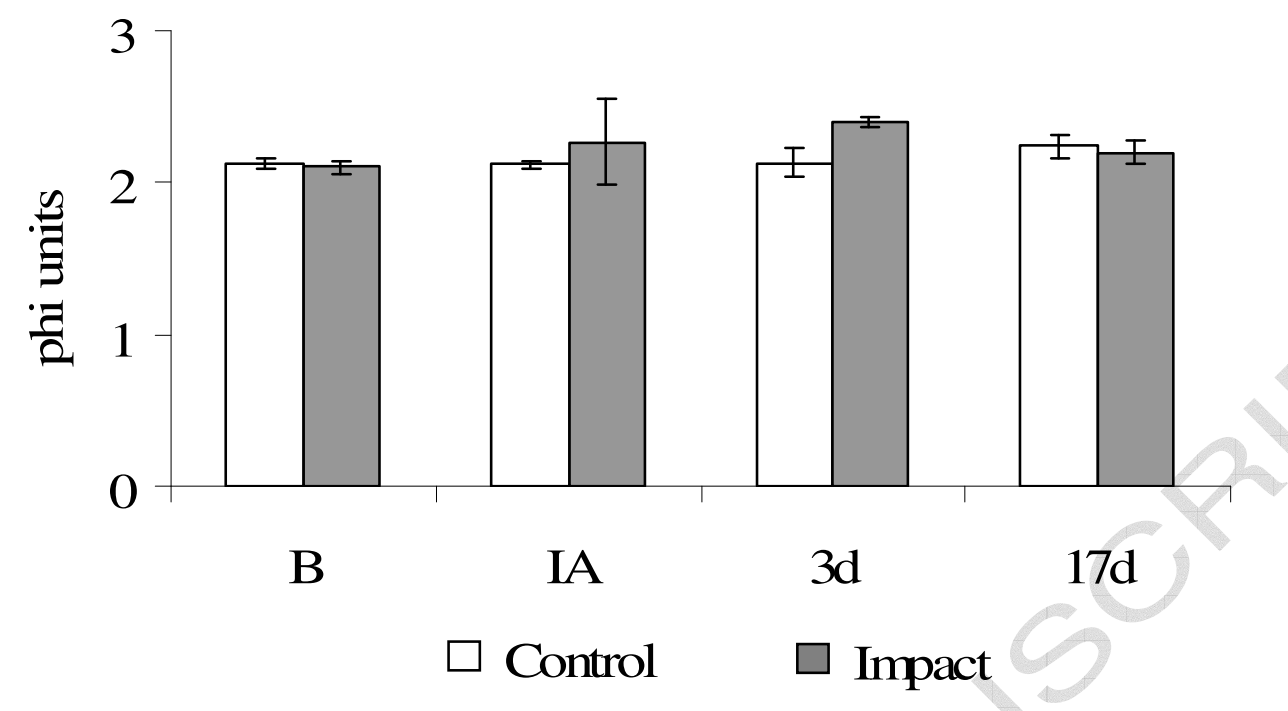

Figure 6 


\section{ACCEPTED MANUSCRIPT}

Fig.7

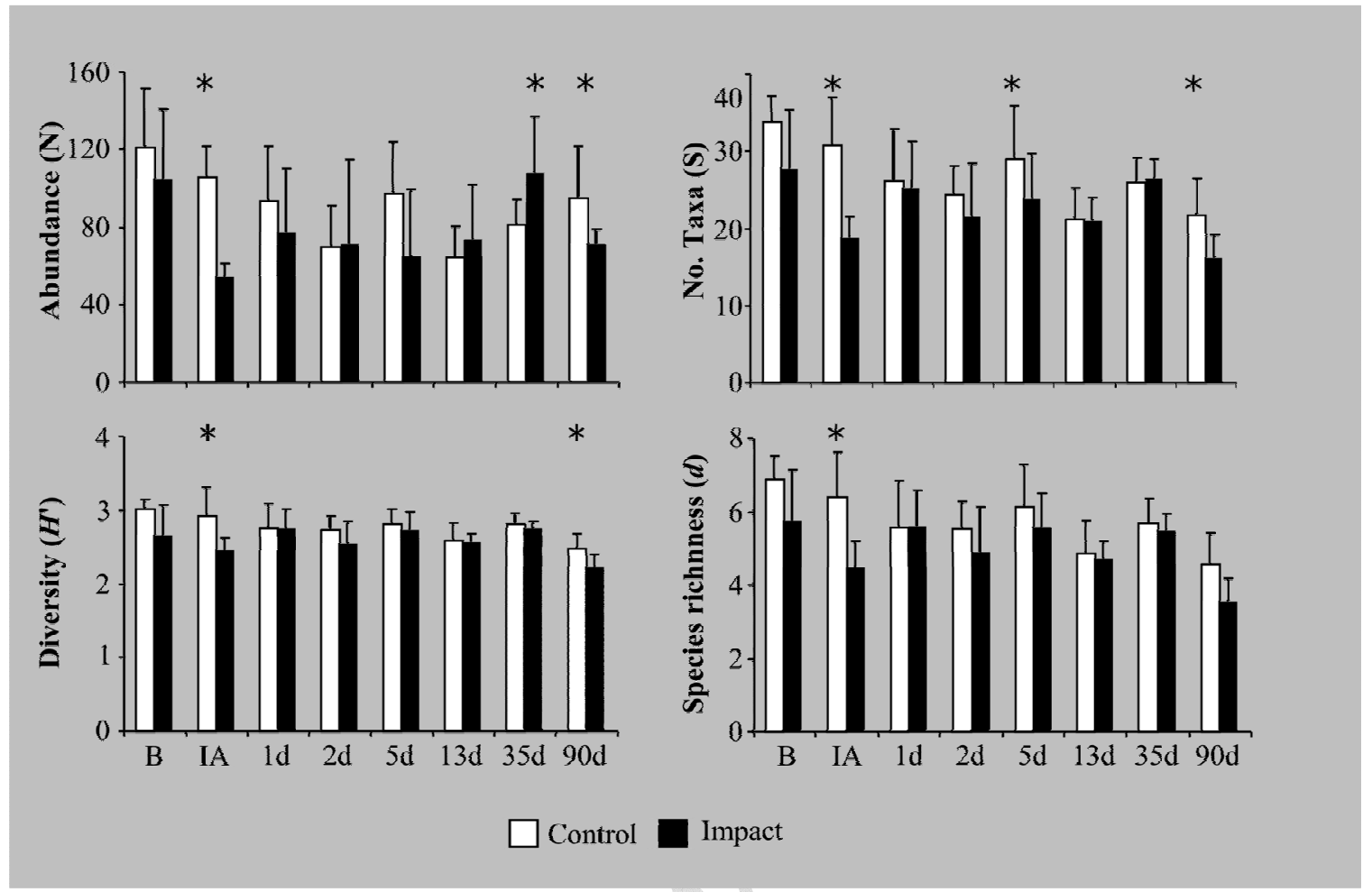




\section{ACCEPTED MANUSCRIPT}

Fig. 8
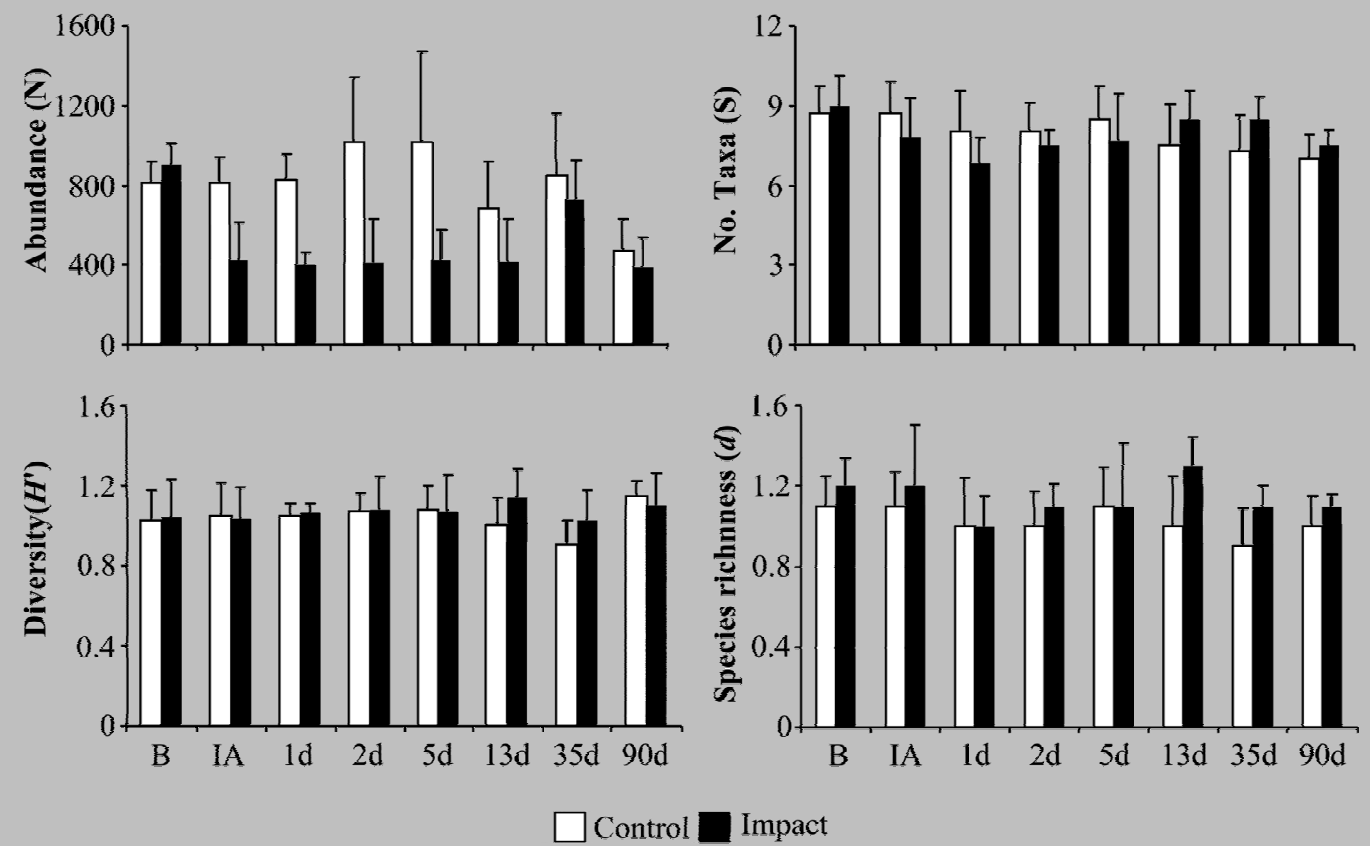


\section{ACCEPTED MANUSCRIPT}

Fig.9

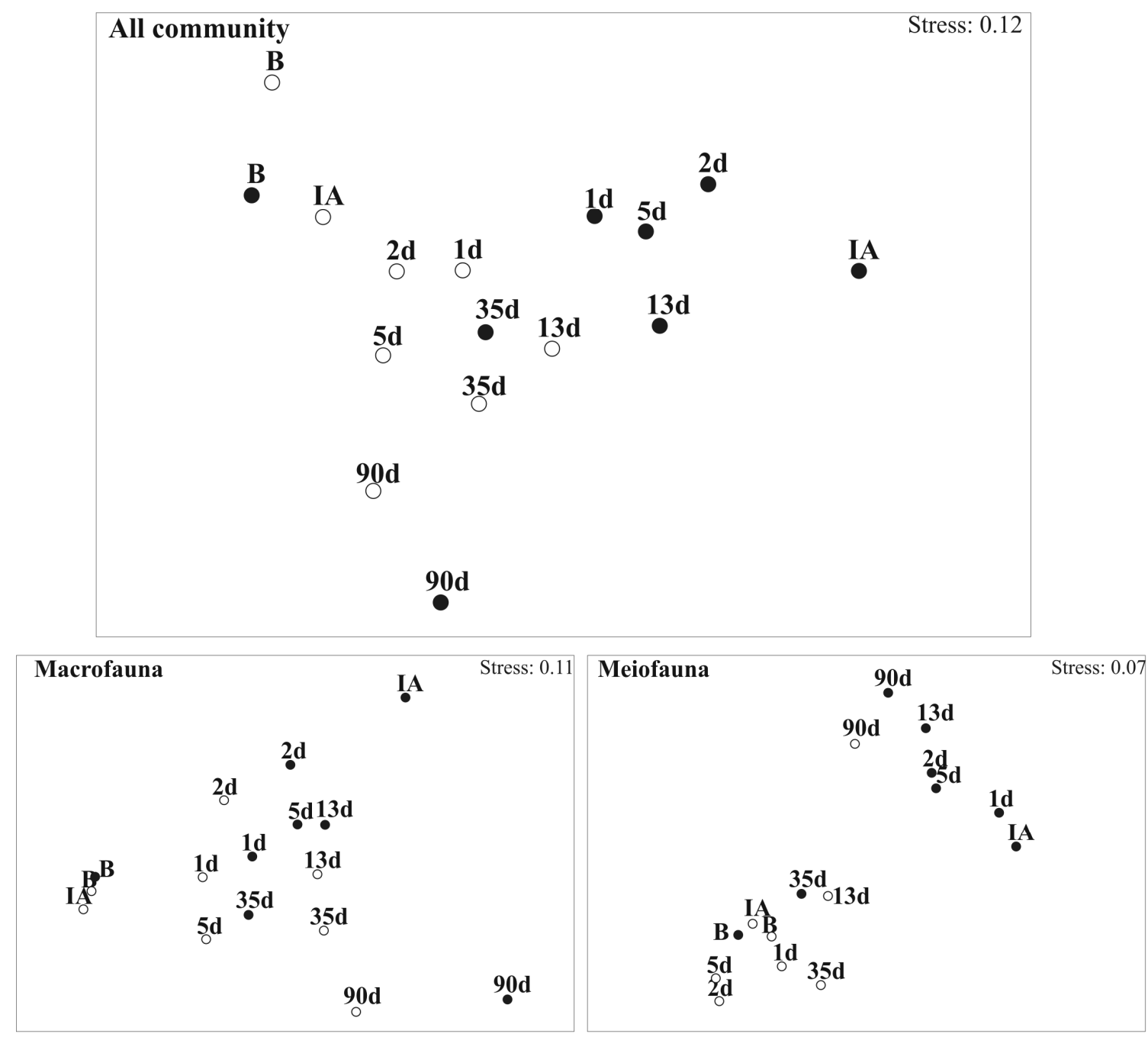




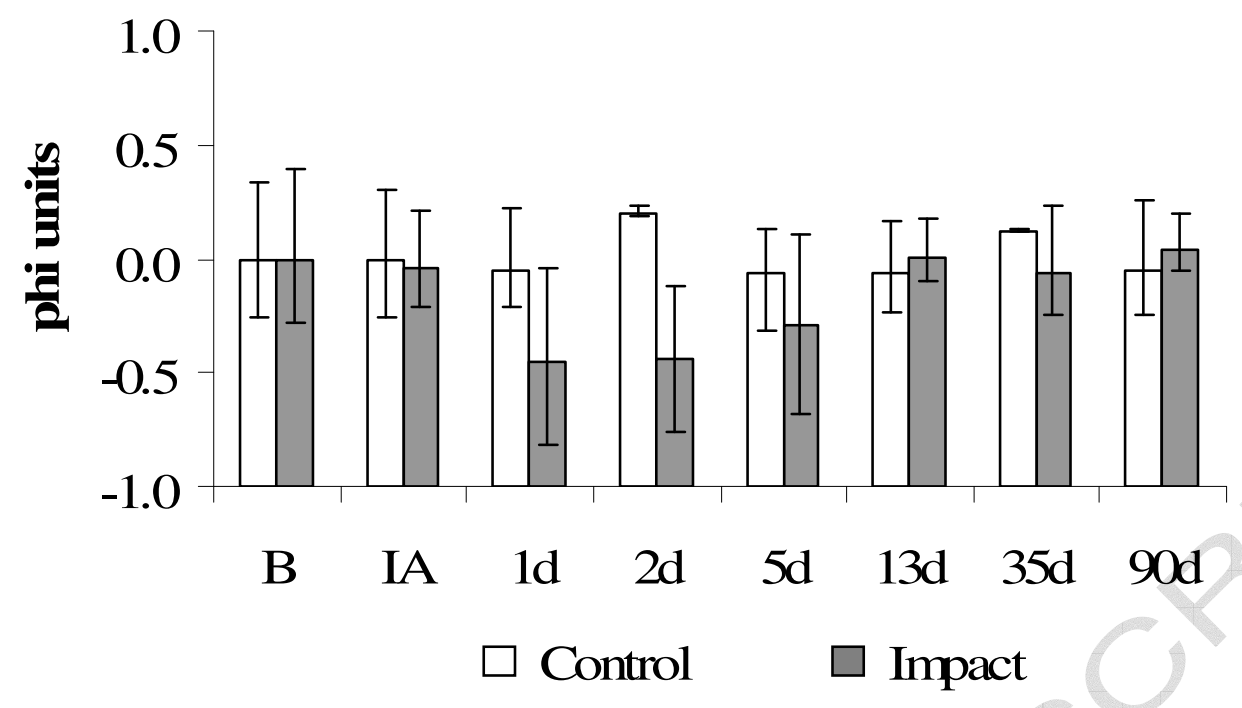

Figure 10 


\section{ACCEPTED MANUSCRIPT}

Table 1 - Percentage of abundance in relation to the sample before dredging at $6 \mathrm{~m}$ depth. Reductions $>40 \%$ are highlighted, while increases $>40 \%$ are presented in bold. AMP Amphipoda; DEC - Decapoda; ISO - Isopoda; NEM - Nemertinea; ECH -

Echinodermata; Mot - motility; FM - feeding mode; EP - external protection; BS - body shape; $\mathrm{C}$ - carnivory; $\mathrm{SF}$ - suspension- feeding; $\mathrm{DF}$ - deposit-feeding; $\mathrm{N}$ - none; $\mathrm{P}$ protection; $\mathrm{S}$ - shell; $\mathrm{S} / \mathrm{CP}$ - scales/chitinous plates; V - vermiform. IA - immediately after; d-days.

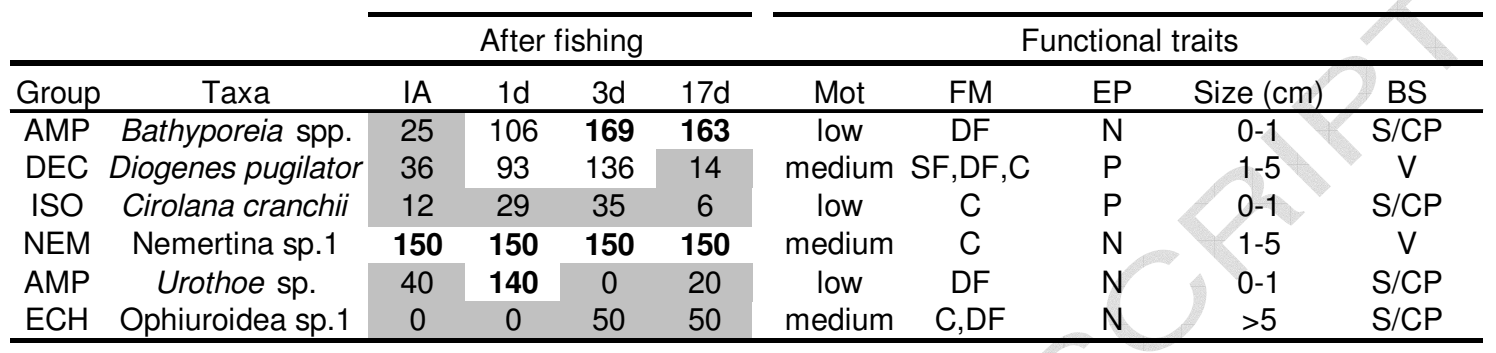


Table 2 - Percentage of abundance in relation to the sample before dredging at $18 \mathrm{~m}$ depth. Reductions $>40 \%$ are highlighted, while increases $>40 \%$ are presented in bold. AMP - Amphipoda; NEB - Nebaliacea; POL - Polychaeta; ECH - Echinodermata; OLI - Oligochaeta; NEM - Nemertinea; SIP - Sipunculida; BIV - Bivalvia; ISO - Isopoda; CEP - Cephalochordata; TAN - Tanaidacea; Mot - motility; FM - feeding mode; EP - external protection; BS body shape; $\mathrm{C}$ - carnivory; $\mathrm{SF}$ - suspension- feeding; $\mathrm{DF}$ - deposit-feeding; $\mathrm{H}$ - herbivory; $\mathrm{N}$ - none; $\mathrm{P}$ - protection; $\mathrm{S}$ - shell; $\mathrm{S} / \mathrm{CP}$ - scales/chitinous plates; V - vermiform. IA - immediately after; $\mathrm{d}$ - days.

\begin{tabular}{|c|c|c|c|c|c|c|c|c|c|c|c|c|c|}
\hline \multirow[b]{2}{*}{ Group } & \multirow[b]{2}{*}{ Taxa } & \multicolumn{7}{|c|}{ After fishing } & \multicolumn{5}{|c|}{ Functional traits } \\
\hline & & IA & $1 d$ & $2 d$ & $5 d$ & $13 d$ & $35 d$ & $90 d$ & Mot & FM & EP & Size $(\mathrm{cm})$ & BS \\
\hline AMP & Cheirocratus sundevalli & 6 & 35 & 47 & 41 & 59 & 18 & 0 & low & $\mathrm{H}, \mathrm{DF}$ & $\mathrm{N}$ & $1-5$ & $\mathrm{~S} / \mathrm{CP}$ \\
\hline AMP & Atylus vedlomensis & 0 & 60 & 30 & 30 & 0 & 40 & 10 & low & C, DF & $P$ & $0-1$ & $\mathrm{~S} / \mathrm{CP}$ \\
\hline AMP & Megamphopus cornutus & 0 & 25 & 19 & 13 & 0 & 13 & 0 & low & SF, DF & $\mathrm{N}$ & $0-1$ & $\mathrm{~S} / \mathrm{CP}$ \\
\hline NEB & Nebalia sp. & 8 & 0 & 8 & 17 & 25 & 17 & 25 & low & $\mathrm{F}$ & $\mathrm{P}$ & $0-1$ & $\mathrm{~S} / \mathrm{CP}$ \\
\hline $\mathrm{POL}$ & Nereididae & 17 & 17 & 8 & 8 & 17 & 8 & 0 & medium & & $\mathrm{N}$ & & V \\
\hline $\mathrm{ECH}$ & Ophiura ophiura & 0 & 30 & 0 & 20 & 10 & 20 & 10 & medium & C, DF & $\mathrm{N}$ & $>5$ & $\mathrm{~S} / \mathrm{CP}$ \\
\hline AMP & Photis cf. longipes & 7 & 24 & 20 & 24 & 30 & 65 & 2 & low & DF & $\mathrm{N}$ & $0-1$ & $\mathrm{~S} / \mathrm{CP}$ \\
\hline POL & Spiophanes bombyx & 4 & 17 & 13 & 17 & 8 & 92 & 13 & sed & DF & $P$ & $1-5$ & V \\
\hline OLI & Oligochaeta sp. 1 & 7 & 0 & 33 & 20 & 0 & 100 & 0 & sed & DF & $\mathrm{N}$ & $0-1$ & V \\
\hline NEM & Nemertina sp. 1 & 0 & 0 & 7 & 63 & 41 & 15 & 22 & medium & C & $\mathrm{N}$ & $1-5$ & V \\
\hline SIP & Aspidosiphonida sp. & 59 & 48 & 58 & 41 & 66 & 81 & 47 & sed & DF, SF & $\mathrm{N}$ & $>5$ & V \\
\hline POL & Hyalinoecia tubicola & 42 & 58 & 50 & 42 & 100 & 100 & 25 & sed & C, DF & $\mathrm{N}$ & $>5$ & V \\
\hline BIV & Corbula gibba & 25 & 92 & 17 & 25 & 17 & 8 & 33 & sed & SF & $\mathrm{N}$ & $1-5$ & S \\
\hline AMP & Leucothoe incisa & 0 & 75 & 42 & 17 & 58 & 108 & 17 & low & DF & $\mathrm{N}$ & $0-1$ & $\mathrm{~S} / \mathrm{CP}$ \\
\hline POL & Micronephtys sp. & 20 & 120 & 40 & 40 & 0 & 60 & 20 & medium & $\mathrm{C}$ & $\mathrm{N}$ & $0-1$ & V \\
\hline AMP & Melitidae sp. 1 & 114 & 42 & 19 & 31 & 13 & 31 & 31 & low & & $P$ & & $\mathrm{~S} / \mathrm{CP}$ \\
\hline POL & Pomatoceros sp. & 63 & 38 & 50 & 13 & 88 & 25 & 0 & sed & SF & $\mathrm{P}$ & $1-5$ & V \\
\hline ISO & Eurydice pulchra & 12 & 76 & 41 & 71 & 41 & 53 & 24 & medium & $\mathrm{C}$ & $\mathrm{P}$ & $0-1$ & $\mathrm{~S} / \mathrm{CP}$ \\
\hline AMP & Leptocheirus pectinatus & 32 & 76 & 45 & 42 & 66 & 163 & 3 & sed & SF & $P$ & $0-1$ & $\mathrm{~S} / \mathrm{CP}$ \\
\hline POL & Sphaerosyllis sp. & 63 & 33 & 46 & 46 & 88 & 138 & 71 & medium & DF & $\mathrm{N}$ & $0-1$ & V \\
\hline CEP & Branchiostoma lanceolatum & 27 & 81 & 68 & 71 & 56 & 78 & 123 & medium & C, DF & $\mathrm{N}$ & $1-5$ & V \\
\hline POL & Notomastus sp. & 38 & 74 & 110 & 49 & 71 & 109 & 53 & sed & DF & $\mathrm{N}$ & $>5$ & V \\
\hline BIV & Gouldia minima & 40 & 160 & 20 & 20 & 100 & 40 & 40 & sed & SF & $\mathrm{N}$ & $1-5$ & S \\
\hline POL & Syllis sp. & 62 & 46 & 54 & 138 & 108 & 115 & 62 & medium & $\mathrm{C}$ & $\mathrm{N}$ & $1-5$ & V \\
\hline POL & Maldanidae & 0 & 300 & 100 & 0 & 50 & 350 & 100 & sed & DF & $\mathrm{N}$ & & V \\
\hline AMP & Monoculodes carinatus & 50 & 150 & 200 & 50 & 350 & 50 & 0 & low & $\mathrm{C}$ & $P$ & $1-5$ & $\mathrm{~S} / \mathrm{CP}$ \\
\hline AMP & Amphipoda sp. 1 & 50 & 150 & 150 & 100 & 200 & 300 & 0 & & & $\mathrm{P}$ & & $\mathrm{S} / \mathrm{CP}$ \\
\hline $\mathrm{POL}$ & Eunicidae & \multicolumn{2}{|c|}{ appeared } & & & & & & low & & $\mathrm{N}$ & & V \\
\hline POL & Goniadella sp. & & & & & & & medium & C & $\mathrm{N}$ & $1-5$ & V \\
\hline POL & Parapionosyllis sp. & \multicolumn{2}{|c|}{ appeared } & & & & & & medium & C & $\mathrm{N}$ & $0-1$ & V \\
\hline POL & Lumbrineriopsis sp. & \multicolumn{2}{|c|}{ appeared } & & & & & & medium & C & $\mathrm{N}$ & $1-5$ & V \\
\hline POL & Protodorvillea kefersteini & 153 & 284 & 163 & 274 & 226 & 274 & 216 & medium & $\mathrm{C}$ & $\mathrm{N}$ & $0-1$ & V \\
\hline POL & Ophelia sp. & 114 & 171 & 143 & 171 & 129 & 514 & 557 & sed & DF & $\mathrm{N}$ & $>5$ & V \\
\hline POL & Nephtys sp. & 67 & 200 & 67 & 233 & 167 & 267 & 67 & medium & C & $\mathrm{N}$ & $>5$ & $\mathrm{~V}$ \\
\hline AMP & Ampelisca spp. & 120 & 300 & 180 & 260 & 380 & 220 & 0 & sed & SF, DF & $P$ & $1-5$ & $\mathrm{~S} / \mathrm{CP}$ \\
\hline POL & Pisione remota & 400 & 407 & 336 & 200 & 429 & 671 & 929 & low & $\mathrm{DF}, \mathrm{H}$ & $\mathrm{N}$ & $0-1$ & V \\
\hline POL & Eunicida & 195 & 284 & 195 & 263 & 216 & 300 & 311 & low & & $\mathrm{N}$ & & V \\
\hline TAN & Apseudes latreillii & 300 & 400 & 400 & 300 & 0 & 0 & 0 & sed & DF & $\mathrm{P}$ & $0-1$ & $\mathrm{~S} / \mathrm{CP}$ \\
\hline
\end{tabular}

